\title{
A Counter-Flow-Based Dual-Electrolyte Protocol for Multiple Electrochemical Applications ${ }^{1}$
}

\author{
Xu Lu ${ }^{1,2,3}$, Yifei Wang ${ }^{3}$, Dennis Y.C. Leung ${ }^{3, *}$, Jin Xuan ${ }^{4, *}$, Huizhi Wang ${ }^{4}$ \\ ${ }^{1}$ Department of Chemistry, Yale University, New Haven, Connecticut 06520, United States \\ ${ }^{2}$ Energy Sciences Institute, Yale University, West Haven, Connecticut 06516, United States \\ ${ }^{3}$ Department of Mechanical Engineering, The University of Hong Kong, Pokfulam Road, Hong \\ Kong \\ ${ }^{4}$ School of Engineering and Physical Sciences, Heriot-Watt University, Edinburgh, U.K \\ * Corresponding authors, Tel.: +852 3917 7911, fax: +852 2858 5415, email: ycleung@hku.hk \\ (D.Y.C. Leung); Tel.: +44(0)1314513293, fax: +44(0)1314513129, email: j.xuan@hw.ac.uk (Jin \\ Xuan)
}

\begin{abstract}
This paper reports a computational demonstration and analysis of an innovative counter-flowbased microfluidic unit and its upscaling network, which is compatible with previously developed dual-electrolyte protocols and numerous other electrochemical applications. This design consists of multidimensional T-shaped microchannels that allow the effective formation of primary and secondary counter-flow patterns, which are beneficial for both high-performance regenerative $\mathrm{H}_{2} / \mathrm{O}_{2}$ redox cells and flow batteries at a low electrolyte flow-rate operation. This novel design demonstrates the potential to achieve high overall energy throughput and reactivity because of the full utilization of all available reaction sites. A computational study on energy and pressure loss mechanism during scale-out is also examined, thereby advancing the realization of an economical electrolyte-recycling scheme.
\end{abstract}

\footnotetext{
${ }^{1}$ The short version of the paper was presented at ICAE2017, Aug 21-24, Cardiff, UK. This paper is a substantial extension of the short version of the conference paper.
} 


\section{Keywords}

Electrochemistry; Microfluidics; Up-scaling; Numerical modelling; High throughput.

\section{Nomenclature}

\begin{tabular}{|c|c|c|c|}
\hline A & active area $\left(\mathrm{cm}^{2}\right)$ & $\mathrm{u}$ & velocity $(\mathrm{m} / \mathrm{s})$ \\
\hline $\mathrm{E}$ & equilibrium potential (V) & $\mathrm{V}$ & voltage $(\mathrm{V})$ \\
\hline $\mathrm{F}$ & faradaic constant $(\mathrm{C} / \mathrm{mol})$ & $\alpha$ & transfer coefficient \\
\hline g & gravitational acceleration $\left(\mathrm{m} / \mathrm{s}^{2}\right)$ & $\gamma$ & stoichiometric coefficients \\
\hline $\mathrm{i}$ & current density $\left(\mathrm{A} / \mathrm{m}^{2}\right)$ & $\tau$ & the viscosity stress tensor $(\mathrm{Pa})$ \\
\hline $\mathrm{j}$ & mass flux $\left(\mathrm{kg} / \mathrm{m}^{2} \cdot \mathrm{s}\right)$ & $\mu$ & viscosity (Pa s) \\
\hline $\mathrm{M}$ & molar mass $(\mathrm{g} / \mathrm{mol})$ & $\rho$ & density $\left(\mathrm{kg} / \mathrm{m}^{3}\right)$ \\
\hline $\mathrm{n}$ & number of participating electrons & $\sigma$ & conductivity (S/m) \\
\hline $\mathrm{n}_{\mathrm{t}}$ & $\begin{array}{l}\text { number of electrons exchanged at the } \\
\text { rate-limiting step }\end{array}$ & $\chi$ & reaction order \\
\hline $\mathrm{p}$ & pressure $(\mathrm{Pa})$ & $\varphi$ & potential $(\mathrm{V})$ \\
\hline $\mathrm{S}_{\mathrm{k}}$ & current source $\left(\mathrm{A} / \mathrm{m}^{3}\right)$ & $\mathrm{w}$ & mass fraction \\
\hline $\mathrm{S}_{\mathrm{i}}$ & $\begin{array}{l}\text { production or consumption rate }(\mathrm{kg} / \\
\left.\mathrm{m}^{3} \cdot \mathrm{s}\right)\end{array}$ & $\eta$ & activation overpotential (V) \\
\hline \multicolumn{4}{|c|}{ Subscript } \\
\hline 0 & reference or boundary & $\mathrm{m}$ & main reaction \\
\hline $\mathrm{a}$ & anode & $\mathrm{p}$ & parasitic reaction \\
\hline c & cathode & ref & reference \\
\hline $\mathrm{i}$ & species i & & \\
\hline
\end{tabular}




\section{Introduction}

In spite of the demonstrated marketability of proton-exchange membrane fuel cells (PEM) [13], their further deployment faces growing economic pressure because of the membrane cost and operating conditions. With its low-cost fabrication and mild operating condition, microfluidic fuel cell technology is regarded as a promising solution for a portable electricity source. Most current research efforts on microfluidic fuel cells focus on the pattern for which the laminar catholyte and anolyte streams flow in parallel [4]. The dual-electrolyte scenarios introduce favorable thermodynamics to multiple electrochemical processes. In the complicated and sensitive process of microfluidic electrochemistry, experimental operating conditions would be highly influential to efficiency, implying the importance of the reactor structure, microporous morphology and physical properties. As the design-based study is time-consuming though necessary for performance optimization, rapid numerical screening is critical. System scale-out is another important application of the proposed numerical model due to the microfluidic system's robust yet low areaspecific performance. With preliminary numerical investigation of the upscaling serpentine's pressure and mass distribution, an experiment-based scale-out could be more specific and effective. A typical example is a dual-electrolyte membraneless $\mathrm{H}_{2} / \mathrm{O}_{2}$ fuel cell proposed by Cohen et al. [5], where co-flow fluids in the microchannel could perform distinctive behaviors with high surfaceto-volume ratios and super-fast mass transfer rates. The $\mathrm{pH}$ environments of anolytes and catholytes in the cell were optimized independently, demonstrating an open-circuit potential in excess of $1.4 \mathrm{~V}$ and a power density of $0.96 \mathrm{~mW} / \mathrm{cm}^{2}$ with oxidant dissolved in $0.1 \mathrm{M} \mathrm{H}_{2} \mathrm{SO}_{4}$ and hydrogen dissolved in $0.1 \mathrm{M} \mathrm{KOH}$. The dual-electrolyte configuration not only rendered an elevated open-circuit voltage in the fuel cell mode but also allowed water electrolysis at a significantly reduced voltage [6]. Inspired by supreme water-splitting performance, the integration of a dual-electrolyte technique in a microfluidic platform was applied to the electrochemical 
conversion of $\mathrm{CO}_{2}$ to fuels. Freed from hindrances of the membrane structure and thermodynamic limitations, electrode potentials were drawn closer to the equilibrium status at higher reactivity. During the conversion of $\mathrm{CO}_{2}$, the peak faradaic and energy efficiencies were monitored with noteworthy improvement and, hence, facilitate the motivation for a broader exploration [7-9].

Indeed, the natural mixing layer between the electrolytes could perform the same role as a physical barrier such as a proton-exchange membrane; however, retaining the characteristics of laminar flow requires a continuous electrolyte supply into the microchannel, leading to considerable electrolyte wastage and low electrolyte-utilization efficiency. To tackle this issue, this study employs a counter-flow design, which was initially proposed to provide effective electrolyte separation in a vanadium redox flow battery with multiple vanadium oxidation states [10] and further developed as a formic acid fuel-cell platform [11]. Figure 1(a) shows a schematic of the counter-flow pattern with air-breathing electrodes. The fuel, formic acid, is dissolved in the anolyte, which is supplied from the right-hand inlet and oxidized at the porous anode. Similarly, the catholyte is introduced from the left-hand inlet, providing a reaction site for the gaseous oxidant penetrating the gas-diffusion anode. Unlike co-flow, the counter-flow pattern creates a mixing region, and the dominant viscous effect stabilizes the interface, preventing the interaction between the fuel and the oxidant [11-13]. The diffusion transfer is suppressed by the opposite convection transfer, and the diffusion time of reactive species is less than their convection time, i.e. residence time. In this way, only a small electrolyte flow rate is required to form this virtual separating layer, allowing a high fuel-utilization operation.

The economic feasibility of microfluidic electrochemistry is also in doubt in spite of its high area-specific performance. Its practicability is severely constrained by the low overall yield due to the inherent reactor size. Dimensional scale-out has been proven infeasible [14] due to the boundary-layer growth and mixing-layer perturbation accompanied by significant energy losses. 
Other efforts, such as two-cell planar array [15], vertical stack [16], and multiplexing flow distribution [17], have suffered from low applicability to practical situations, where the fluid maldistribution is far more complex. Therefore, a new upscaling path needs to be developed for mass production and industrial applications. This could be achieved based on the above-mentioned microfluidic platform; our group [18] and others [19] have demonstrated its capability for efficient system scale-out. Based on these genetic mechanisms, a microfluidic multidimensional modularization design will be proposed. Performance losses during the scale-out will be minimized by an effective liquid-redistribution strategy. A two-dimensional shunt serpentine (Figure 1(b)) and upscaling networks (Figure 1(c)) will then be numerically established.

$\rightarrow$ Catholyte

$\rightarrow$ Anolyte

(a)

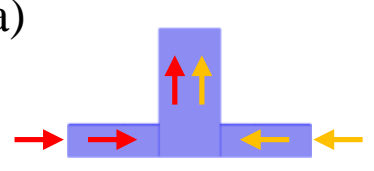

(b)

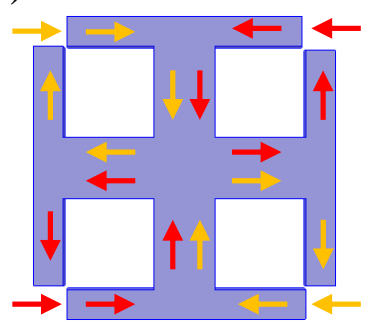

(c)

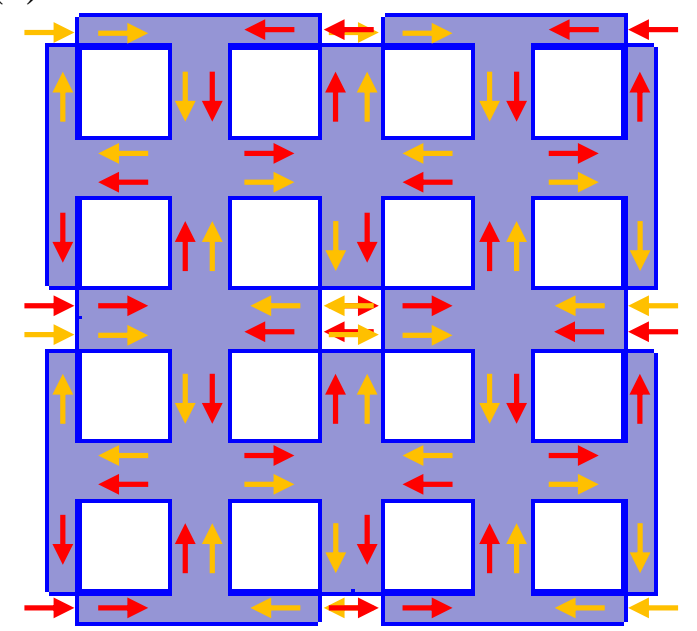

Figure 1. Schematics of counter-flow based fuel cell (a) unit, (b) module, and (c) up-scaling network.

\section{Numerical Model}

\subsection{Basic assumptions}

The finite element analysis software, COMSOL Multiphysics, is used to determine the flow pattern and electrochemical performance of the upscaling network. We make the following assumptions and simplifications during the calculation: 
- The system is isothermal and in a steady state. This is a reasonable assumption for an electrochemical cell with flowing electrolytes;

- The electrolyte is an incompressible Newtonian fluid, and the flow is laminar;

- The gas is weakly compressible, and the flow in the gas channel is laminar;

- The side walls of the cell are impermeable, and the slip is zero;

- A zero-concentration gradient along the cell cross-section, as the no-slip condition and zero species flux at the left and right walls of the cell, is assumed;

- The fluid's properties, including density and viscosity, are not influenced by the solute concentration.

It should be noted that in a microfluidic scenario, the Knudsen number is less than 0.001 [20], hence the validity of a non-slip condition should be applied. The structured quadrilateral grid was constructed throughout the laminar flow domain, for which the length of the element edge varied from 1.11 to $3.71 \mu \mathrm{m}$. A grid independence test was conducted by changing the number of elements from 9,546 to 333,994 to achieve a consistent outcome with a difference of less than $0.1 \%$.

\subsection{Microfluidic characterization}

The low Reynolds number ( $\mathrm{Re})$, as mentioned below, which is used to verify the microfluidic characteristics of the geometry, is calculated by:

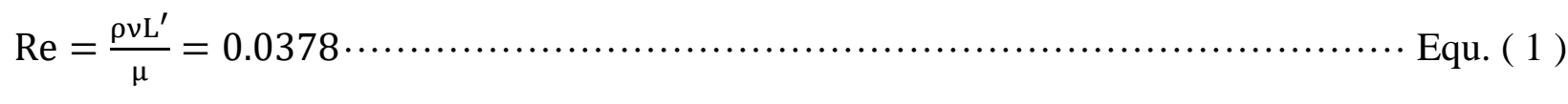
where $L^{\prime}=0.28 \mathrm{~mm}$ is the hydraulic diameter of the channel in the proposed design, $v=0.135 \mathrm{~m} / \mathrm{s}$ is the characteristic velocity for Reynolds number calculation.

\subsection{Hydrodynamics}

For a microfluidic network, continuity equation, conservation equation of species, and the steady-state Navier-Stokes equation are applicable without the problematic convective term: 
$\nabla \cdot(\rho \mathrm{u})=0$

$\nabla \cdot\left(\rho \mathrm{w}_{\mathrm{i}} \mathrm{u}\right)=-\nabla \cdot \mathrm{j}_{\mathrm{i}}+\mathrm{S}_{\mathrm{i}}$

$\nabla \mathrm{p}=\mu \nabla^{2} \mathrm{u}$

where $\mu=1 \mathrm{mPa} \cdot \mathrm{s}$ is the fluid viscosity, $\mathrm{u}$ is the fluidic velocity $(\mathrm{m} / \mathrm{s}), \mathrm{w}_{\mathrm{i}}$ is the mass fraction of species involved, $j_{i}$ is the mass flux of species involved $\left(\mathrm{kg} / \mathrm{m}^{2} \cdot \mathrm{s}\right), \mathrm{S}_{\mathrm{i}}$ is the production or consumption rate $\left(\mathrm{kg} / \mathrm{m}^{3} \cdot \mathrm{s}\right)$.

The density $\rho$ of the formic acid solution is aligned to the literature [11]:

$\rho=1011+208 \cdot \mathrm{w}_{\mathrm{fa}}$ Equ. ( 5 )

where $\mathrm{w}_{\mathrm{fa}}$ is the mass fraction of formic acid.

\subsection{Mass transfer}

The Maxwell-Stefan expression is used to describe the diffusive transport. The mass-balance equations for the solute are:

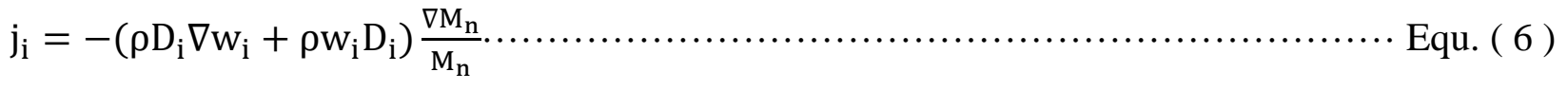

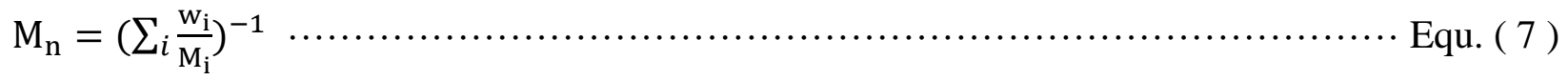

where $D_{i}$ is the diffusion coefficient $1.6 \times 10^{-8} \mathrm{~m}^{2} / \mathrm{s}, M_{i}$ is the molar mass of species involved $(\mathrm{g} / \mathrm{mol})$.

The situation where the viscosity depends quadratically on the concentration occurs in solutions of macromolecules. For $\mathrm{H}_{2} \mathrm{SO}_{4}$, it can be assumed that a change in solute concentration does not influence the fluid's density and viscosity. This implies that it is possible to first solve the NavierStokes equations and then solve the mass balance equation. COMSOL automatically includes the stabilization by default, so no explicit settings are required. To ensure no misinterpretation of the 
simulation results on the micromixing process, the $\mathrm{pH}$ profile across the cross-section of the microchannel from the experimental data and our previous protocol will also be presented.

\subsection{Electrochemical kinetics and overpotentials}

The reaction at the cathode, which is also the anode parasitic reaction, is:

$2 \mathrm{HCOOH} \rightarrow 2 \mathrm{CO}_{2}+4 \mathrm{H}^{+}+4 \mathrm{e}^{-}$

The reaction at the anode, which is also the cathode parasitic reaction, is:

$\mathrm{O}_{2}+4 \mathrm{H}^{+}+4 \mathrm{e}^{-} \rightarrow 2 \mathrm{H}_{2} \mathrm{O}$

The parasitic current is considered to be 0 , as its presence could significantly affect cell performance due to fuel crossover.

The electrochemical kinetics for the main and parasitic reactions is governed by the ButlerVolmer equation, where the oxidant crossover could be neglected because of the low solubility of gaseous oxygen:

$$
\begin{aligned}
& i_{c}=i_{0, c}\left(\frac{c_{0}}{c_{0, \text { ref }}}\right)^{\chi}\left(e^{\frac{\alpha_{a} n_{t} F \eta}{R T}}-e^{\frac{-\alpha_{c} n_{t} F \eta}{R T}}\right)+i_{0, a}\left(\frac{c_{f}}{c_{f, r e f}}\right)^{\chi}\left(e^{\frac{\alpha_{a} n_{t} F \eta}{R T}}-e^{\frac{-\alpha_{c} n_{t} F \eta}{R T}}\right) \\
& i_{a}=i_{0, a}\left(\frac{c_{f}}{c_{f, r e f}}\right)^{\chi}\left(e^{\frac{\alpha_{a} n_{t} F \eta}{R T}}-e^{\frac{-\alpha_{c} n_{t} F \eta}{R T}}\right) \\
& \eta=\varphi_{\mathrm{s}}-\varphi_{\mathrm{l}}-\mathrm{E}
\end{aligned}
$$

where $\mathrm{i}_{\mathrm{c}}=0.06 \mathrm{~A} / \mathrm{m}^{2}$ and $\mathrm{i}_{\mathrm{a}}=0.004 \mathrm{~A} / \mathrm{m}^{2}$ are the exchange current density of cathode and anode reactions $\left(\mathrm{A} / \mathrm{m}^{2}\right)$, respectively, $\mathrm{c}_{0}=0.25 \mathrm{~mol} / \mathrm{L}$ is the oxidant concentration, $\mathrm{T}=298 \mathrm{~K}$ is the temperature, $\alpha_{\mathrm{a}}=\alpha_{\mathrm{c}}=0.5$ are the anodic and cathodic transfer coefficients, respectively, $\mathrm{n}_{\mathrm{t}}$ is the number of electron transfer, $\mathrm{c}_{\mathrm{f}, \mathrm{ref}}=1000 \mathrm{~mol} / \mathrm{L}$ and $\mathrm{c}_{\mathrm{o}, \mathrm{ref}}=1.25 \mathrm{~mol} / \mathrm{L}$ are the reference fuel 
and oxidation concentrations, respectively, $\eta$ is the overpotential (V), F is the Faraday constant $(\mathrm{C} / \mathrm{mol}), \chi$ is the reaction order.

The sink and source of reactant species are determined by:

$S_{i}=M_{i} \frac{\gamma_{i} \nabla \cdot i}{n_{i} F}$

$\nabla \cdot \mathrm{i}=-\sigma \Delta \varphi$

where Equ. 14 relates the potential and current, $\sigma$ is the conductivity $(\mathrm{S} / \mathrm{m}), \varphi$ is the potential (V), $\gamma_{\mathrm{i}}$ is the stoichiometric coefficients of the species involved.

\subsection{Boundary conditions and key parametric input}

The boundary conditions are prescribed in Table 1 .

Table 1. Boundary conditions.

\begin{tabular}{l|l}
\hline Position & Condition \\
\hline Inlet & $\begin{array}{l}\text { constant species mass fraction } \\
\text { constant inlet velocity }\end{array}$ \\
\hline Electrodes & $\begin{array}{l}\text { zero-diffusive flux of species } \\
\text { constant outlet pressure }\end{array}$ \\
\hline Wall & non-flux boundaries \\
\hline Solution phase & $\begin{array}{l}\text { non-slip condition } \\
\text { constant potentials at the electrodes }\end{array}$ \\
\hline
\end{tabular}

\section{Experimental validation}

To verify the concept, an optical microscope measurement was conducted with a cell built on the same cross-shape geometry as the numerical model (Figure 1b). A 0.5 -mm-thick polyvinyl chloride (PVC) plates with a cross-shape window cut out was used to define the reactive area and channels. Two layered 0.1-mm-thick PVC plates was used to create the inlets of an alkaline and an 
acid solution, capped by another plate to seal the cell. All layered components were fabricated using a carbon dioxide laser ablation system (VLS 2.30, Universal Laser System) and clamped together by binder clips (Highmark). Prior to the experiments, a leakage test was carried out by immersing the cell into a beaker filled with water when passing nitrogen through the gas channels.

For optical visualization, uncolored deionized water and deionized water dyed by $1000 \mathrm{ppm}$ methyl orange were supplied to the cell at varied flow rates.

For fluorescence microscopy, we dissolved $0.25 \mathrm{mM}$ fluorescein sodium salt $\left(\mathrm{C}_{20} \mathrm{H}_{10} \mathrm{Na}_{2} \mathrm{O}_{5}\right.$, Sigma-Aldrich) in the streams of $1.5 \mathrm{M} \mathrm{KOH}$ and $1.5 \mathrm{M} \mathrm{H}_{2} \mathrm{SO}_{4}$ as a $\mathrm{pH}$-sensitive fluorescent dye. The electrolytes were supplied to the assembled cell at flow rates of $500 \mu \mathrm{L} / \mathrm{min}$. The fluorescent dye was excited using a blue light source at a wavelength of 460-490 nm (Intensilight C-HGFI, Nikon). At this wavelength, the absorbance of $\mathrm{C} 20 \mathrm{H} 10 \mathrm{Na} 2 \mathrm{O} 5$ is nearly independent of the $\mathrm{pH}$ value, whereas the emission increases with increasing $\mathrm{pH}$. The fluorescence images were acquired using an inverted fluorescence microscope with 4× objective (Eclipse TE2000-U, Nikon). The gain remained constant at 1 and the exposure time was fixed at $60 \mathrm{~ms}$.

\section{Results and Discussion}

In this simulation, the maximum Re is 0.04 , which is far less than 1 . The low Reynolds number indicates that the electrolytes flow laminarly through the microchannels; however, fuel crossover may still occur in the mixing regime of a counter-flow-based cell due to the overwhelming convection over diffusion. Therefore, it is necessary to evaluate the interfacial mixing patterns of the upscaling network to prove the effectiveness of the concept. At the low flow-rate region (Figure $2(\mathrm{a}-\mathrm{c}))$, i.e. $<1000 \mu \mathrm{L} / \mathrm{min}$, the mixing layer thickness decreases with higher flow rates and no pressure-driven secondary counter-flow is generated at the cross zone (Figure 2(a2)) due to the pressure loss along the primary inlet channel. 
This trend is reversed beyond the flow rate of $1000 \mu \mathrm{L} / \mathrm{min}$ for the unit cell. More and more clearly observable disturbances can be found at the mixing layer (Figure 2(d1-g1)) and become significantly perturbative at $2500 \mu \mathrm{L} / \mathrm{min}$. Meanwhile, at the same flow-rate region, higher flow rates start enabling the formation of a secondary counter-flow pattern, which could be better illustrated by plotting the mass fraction distribution maps of the electrolyte (Figure $2(\mathrm{~d} 4-\mathrm{g} 4)$ ), i.e. sulfuric acid solution. This phenomenon results from the fact that in an upscaling network, the excessive pressure drop and consequent strong convection transfer would be relieved to fill in the 'pressure vacuum' cross zone, creating a secondary driven force for the secondary convection transfer to suppress the diffusion transfer.

(a)

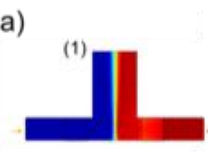

(b)

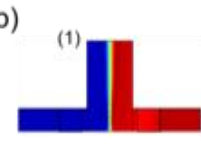

(c)

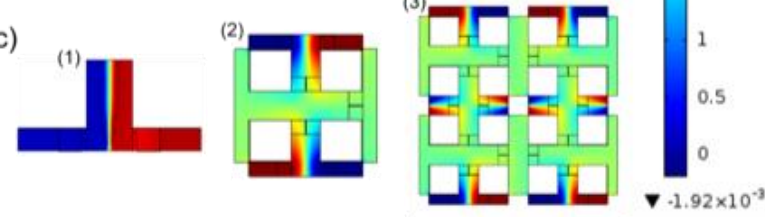

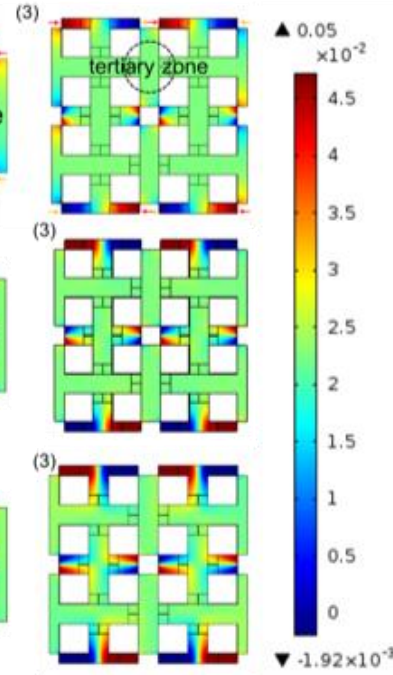

(d)
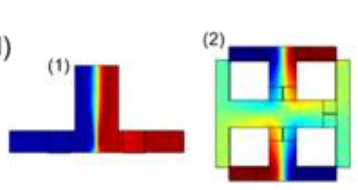

(e)
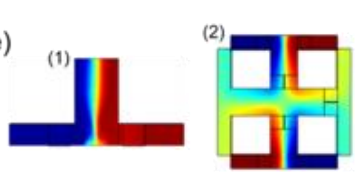

(f)
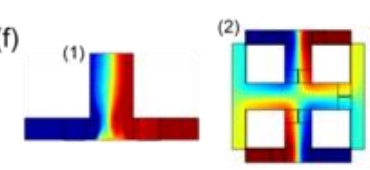

(g)

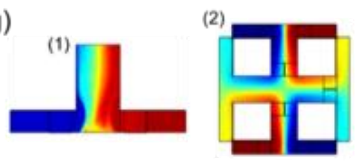

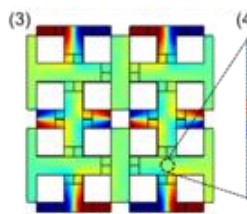
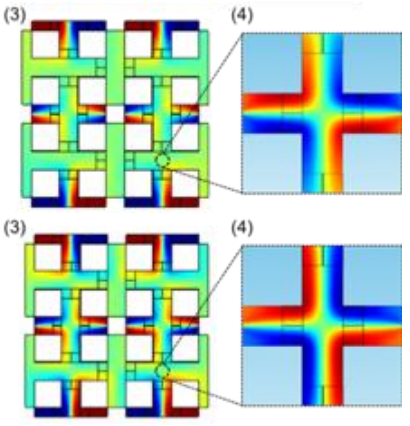

(4)
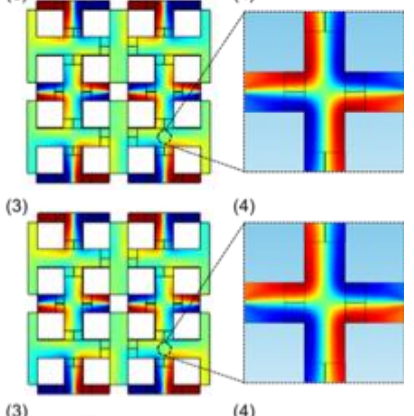

(4)

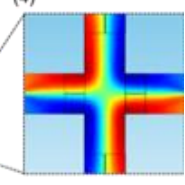

(4)

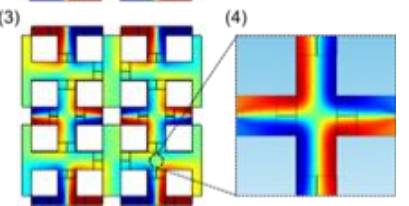

Figure 2. Mass fraction distribution maps of formic acid obtained at flow rates of (a) 100, (b) 500, (c) 1000, (d) 1500, (e) 2000, (f) 2500, and (g) $3000 \mu \mathrm{L} / \mathrm{min}$ from (1) unit, (2) module, and (3) upscaling network. (4) Electrolyte mass fraction distribution maps at the cross zone.

The effect of flow rates on the performance of reactors at different scales is also examined. The transverse comparison across flow rates demonstrates its insignificant influence on the unit cell 
(Figure 3(a)), as the anolyte and catholyte are always well separated, even with the strong interferential convection at high flow rates. In contrast, the electrochemical performance of a module (Figure 3(b)) and upscaling network (Figure 3(c)) is slightly improved with increasing flow rates, reflecting the engagement of the secondary counter-flow pattern at the cross zone. Near the peak power density regime, i.e. output voltage $\sim 0.2 \mathrm{~V}$, the current density output by a unit cell is $\sim 20 \mathrm{~mA} / \mathrm{cm}^{2}$, whilst that of a module or upscaling network is maintained at $\sim 25 \mathrm{~mA} / \mathrm{cm}^{2}$. The limiting current density of the upscaling network $\left(\sim 180 \mathrm{~mA} / \mathrm{cm}^{2}\right)$ is more than twice as much as that of a unit cell $\left(\sim 70 \mathrm{~mA} / \mathrm{cm}^{2}\right)$. This validates the formation and effectiveness of the secondary counter-flow pattern, which doubles the reactive area to collect the waste convection energy.
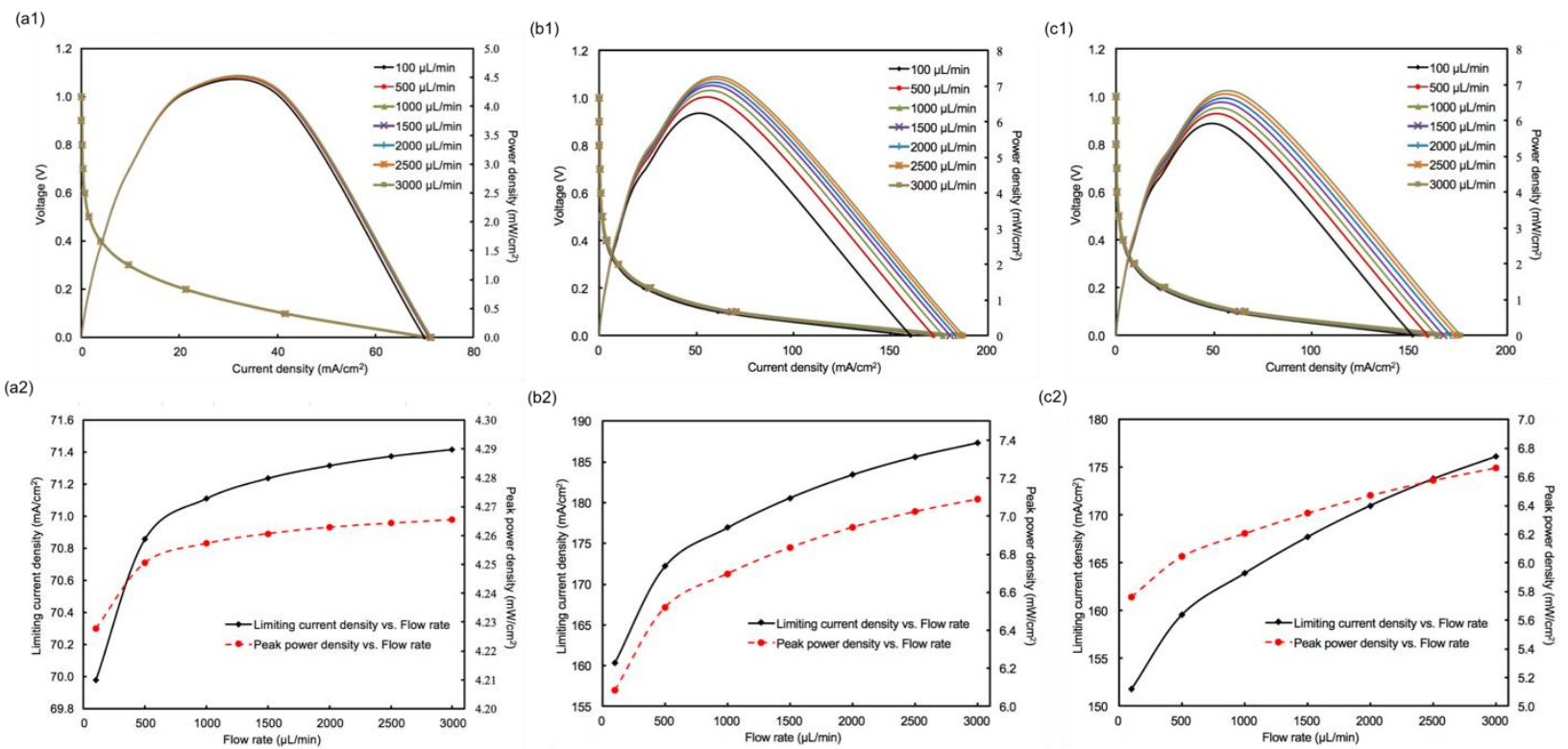

Figure 3. Polarization curves obtained from (a1) unit, (b1) module, (c1) up-scaling network at different flow rates, and limiting current densities/peak power densities vs. flow rates from (a2) unit, (b2) module, (c2) up-scaling network.

An upscaling network is actually 4 modules that are electrically in parallel, and a module consists of 4-unit cells. Considering a single electrode area of $\mathrm{L}=\mathrm{W}=1 \mathrm{~mm}$, there are 1,4 , and 20 coupled reactive sites in a unit, module and upscaling network. It should also be noted that there are 4 more 
coupled sites in an upscaling network than linear multiple because tertiary counter-flow forms at the interconnection zone of adjacent modules (Figure 2(a-3)). Therefore, the overall peak power density outputs of a unit, module and upscaling network are 0.04, 0.28 and $1.33 \mathrm{~mW}$, respectively, and could be linearly increased by further stacking. Numerical data also shows a slight limiting reactivity decrease of the higher scale network $\left(\sim 175 \mathrm{~mA} / \mathrm{cm}^{2}\right.$ vs. $\left.\sim 185 \mathrm{~mA} / \mathrm{cm}^{2}\right)$. This implies an upscaling efficiency of $95 \%$ in an ideal condition. Taking frictional loss and uneven pressure distribution into account, a target of $85 \%$ upscaling efficiency can be established.

As indicated by the performance data of dual-electrolyte fuel cells and electrolyzers stated in Table S1, different acid-alkaline concentrations can result in variable thermodynamic potentials, as can be theoretically predicted by a Pourbaix diagram. These concentrations in the literature were also included in the model and are shown in Figure 4 to identify their feasibility of being incorporated with a counter-flow structure and upscaling strategy. As demonstrated, an insignificant influence of the electrolyte concentration could be found on the interelectrolyte 
mixing layer, regardless of the primary, secondary or tertiary zones. A similar modelling protocol has been applied in our previous numerical study, which has been verified by experiment [21].

(a)

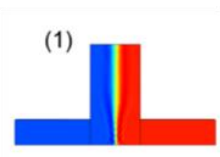

(2)

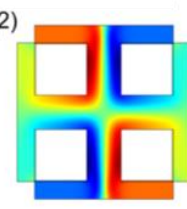

(b)

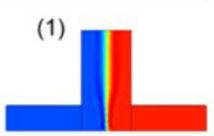

(2)
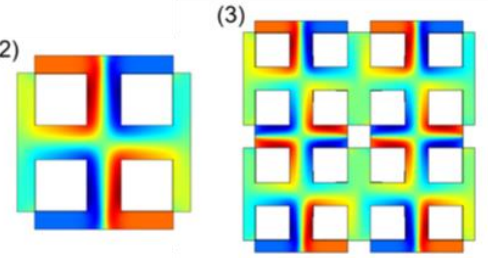

(3)

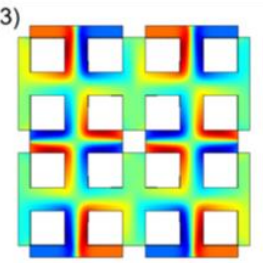

(c)

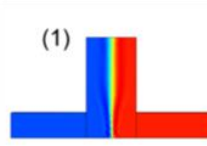

(2)

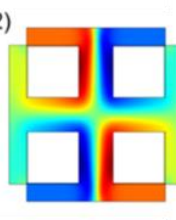

(3)

(3)

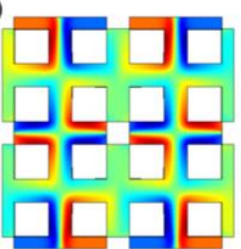

(d)
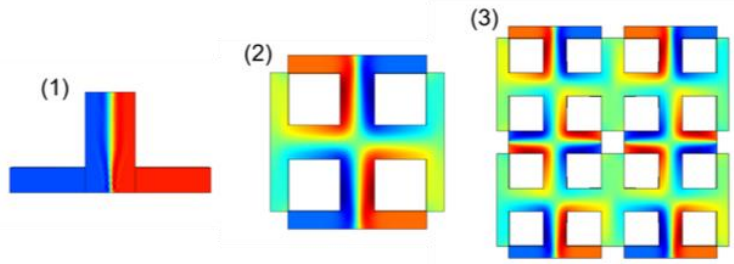

(e)

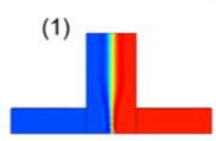

(2)

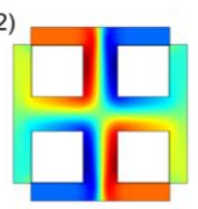

(3)

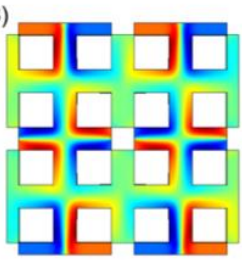

Figure 4. Mass fraction distribution maps of sulfuric acid in acid-base configurations at concentrations of (a) 0.1, (b) 1, (c) 2, (d) 3, (e) 3.5 M from (1) unit, (2) module, and (3) up-scaling network. The electrolyte flow rate was constant at $1000 \mu \mathrm{L} / \mathrm{min}$.

Experimental validation was conducted to verify the formation of the primary and secondary counter flow as demonstrated by the model. Optical visualization was firstly implemented. As demonstrated by Figure 5, a clear separation of the pure deionized water (blue arrow) and the dyed water (orange arrow) could be observed at both the primary and the secondary counter flow regime. This phenomenon could be observed at flow rates as low as $50 \mu \mathrm{L} / \mathrm{min}$. It should be noted that the 
formation of the stable secondary counter flow at a flow rate that is lower than the modelling result is due to the absence of anion and cation.

(a)

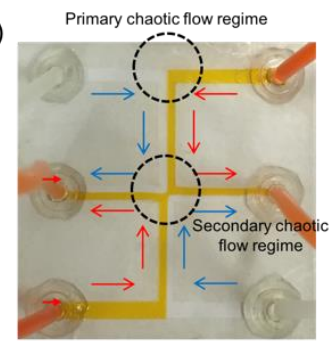

(c)

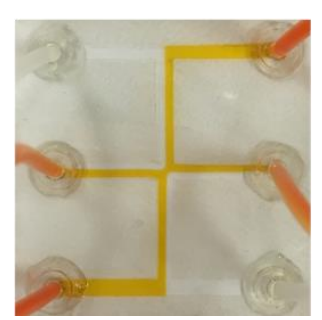

(b)

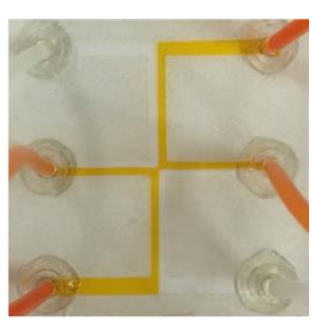

(d)

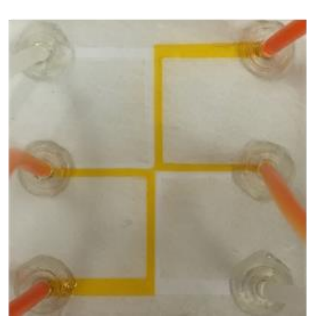

Figure 5. Methyl orange dye enhanced visualization of the primary and secondary counter flow regimes at the flow rate of (a) $1000 \mu \mathrm{L} / \mathrm{min}$; (b) $500 \mu \mathrm{L} / \mathrm{min}$; (c) $100 \mu \mathrm{L} / \mathrm{min}$; and (d) $50 \mu \mathrm{L} / \mathrm{min}$.

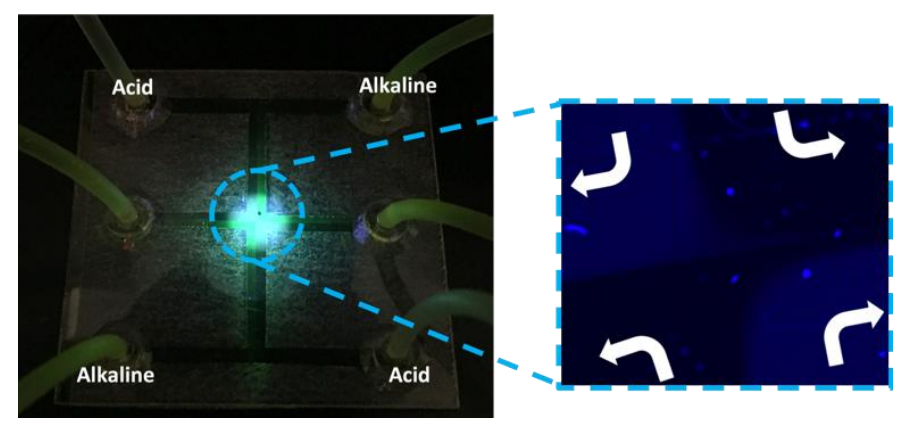

Figure 6. Fluorescence microscopy of the secondary counter flow regime.

With the cell being verified as an effectual counter flow generator, $\mathrm{KOH}$ and $\mathrm{H}_{2} \mathrm{SO}_{4}$, both at 1.5 M concentration, were added to the solutions to further investigate the effectiveness of the proposed design (Figure 6). Images confirm that the interfacial layer thickness between the acid and alkaline 
streams remain low and no severe neutralization occurs to be disruptive. This is attributed to the separation effect of the counter flow as the numerical model indicated.

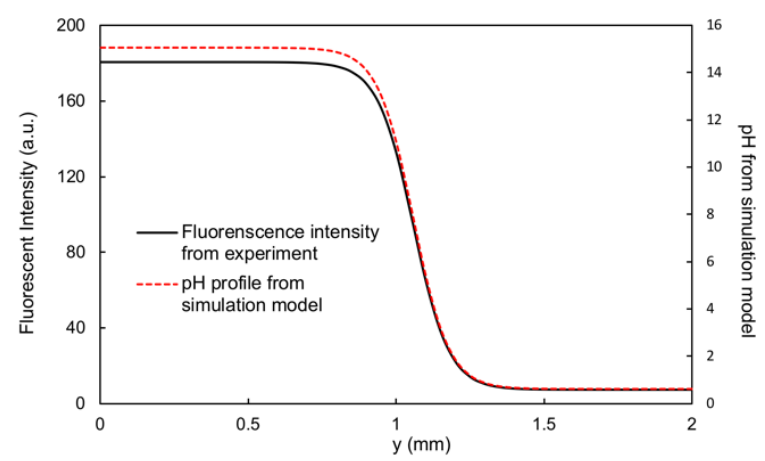

Figure 7. pH profiles in simulation model vs. Experimental observation.

The experiment is used to verify the accuracy of the model, as the numerical diffusion problem could occur due to the stabilization method incorporated in the software. Figure 7 demonstrates the simulated $\mathrm{pH}$ profiles across the cross-section of the micro-channel versus the experimental data. It should be noted that the local $\mathrm{pHs}$ are reflected by the fluorescent intensities in the experimental setup. From the plots, the $\mathrm{pH}$ map as output by the simulation model matches well with that in a real cell. The convection-diffusion synergy could directly influence the local electrolyte pHs, which directly determines the electrochemical performance of the electrode; therefore, the verification could also be vindicated by our previous protocol, which demonstrates the match of the experimental cathode polarization with that output by the simulation model [21].

\section{Future Research and Possibilities}

Besides fuel cells, flow batteries and electrolyzers, Li-air batteries could also benefit from this innovation, which has demonstrated a solution regarding high-energy density power sources attributed to high electrode capacities and output voltages [22]. The first generation of this type of reactor was based on an Li-oxygen couple supported by an aprotic electrolyte. The wide electrochemical window of the organic electrolyte utilized in $\mathrm{Li}$-ion batteries enabled the high output voltage of $\sim 4 \mathrm{~V}$ [23]. However, the life cycle was found to be poor due to the 
dehumidification treatment required to maintain the $\mathrm{Li}$ anode and the non-aqueous electrolyte. Blockage of the air-breathing cathode might occur because of the production of insoluble lithium oxides. In addition, the conventional cathode limited the battery reversible capacity within 140 $\mathrm{mAh} / \mathrm{g}$, and its slow electrode kinetics restricted the output power density. In cathode materials in $\mathrm{Ni}-\mathrm{MH}$ batteries, such as $\beta-\mathrm{Ni}(\mathrm{OH})_{2}$ and $\mathrm{LaNi}_{5} \mathrm{H}_{\mathrm{x}}$, a high capacity of $\sim 300 \mathrm{mAh} / \mathrm{g}$ has been demonstrated, but limited output voltage was observed due to their utilization of aqueous electrolytes [24-26]. To maintain one advantage without sacrificing the other, dual-electrolyte integration was proposed, where an Ni hydroxide cathode in an aqueous electrolyte was coupled with an Li metal anode in an organic electrolyte. This novel system was reported to exhibit a capacity of $264 \mathrm{mAh} / \mathrm{g}$, close to that of a $\beta-\mathrm{Ni}(\mathrm{OH})_{2}$-based battery; a discharge capacity of 261 $\mathrm{mAh} / \mathrm{g}$ at $0.2 \mathrm{~A} / \mathrm{g}$; a cell voltage of $3.47 \mathrm{~V}$; and an ultrahigh theoretical energy density of 428 $\mathrm{Wh} / \mathrm{kg}$. A lithium superionic conductor (LISICON) film was used to separate the electrolytes, and it was experimentally validated to be stable at $95 \%$ during a cyclic test [27]. This idea was also implemented in a $\mathrm{Mn}_{3} \mathrm{O}_{4}$ - $\mathrm{Li}$ battery with a $\mathrm{Li}$ - organic electrolyte - LISICON aqueous $\mathrm{KOH}$ solution $\mathrm{Mn}_{3} \mathrm{O}_{4}$ air-diffusion electrode, achieving a special capacity of $50,000 \mathrm{mAh} / \mathrm{g}$ based on the total mass of the catalytic electrode [28]. However, the generated LiOH precipitation would damage the stability of LISICON. He et al. proposed a distillation strategy to recycle the LiOH product activated by the heat of a vehicle's engine, thereby improving the theoretical energy density to $5058 \mathrm{Wh} / \mathrm{kg}$ and the LISICON performance [29]. Li et al. upgraded this dual dualelectrolyte battery structure by utilizing a moderate $\mathrm{pH}$ phosphate buffer solution to achieve better LISICON durability, which exhibited superior stability for 20 cycles at a current density of 0.5 $\mathrm{mA} / \mathrm{cm}^{2}$ with a discharge capacity of $221 \mathrm{mAh} / \mathrm{g}$ and an energy density of $770 \mathrm{Wh} / \mathrm{kg}$ [30]. Efforts for LISICON development were not limited to its own material composition; it was found that a more more-abundant Na-ion solid electrolyte could be possible with higher conductivity and a 
thinner configuration [31]. An $\mathrm{Na}$ ionically conductive composition was proposed to be incorporated with the active metal anode in an Li-air battery to protect it from degradation under deleterious reactions and ambient conditions [32]. Since its appearance, this NASICON-type water-stable solid electrolyte $\left(\mathrm{Li}_{1+x+y} \mathrm{Al}_{\mathrm{x}} \mathrm{Ti}_{2-\mathrm{x}} \mathrm{Si}_{\mathrm{y}} \mathrm{P}_{3-\mathrm{y}} \mathrm{O}_{12}\right.$ or LTAP) has been widely implemented. Zhang et al. have coupled the LTAP glass ceramic anode with an aqueous $\mathrm{CH}_{3} \mathrm{COOH}-\mathrm{H}_{2} \mathrm{O}-$ $\mathrm{CH}_{3} \mathrm{COOLi}$ electrolyte to stabilize the solid electrolyte in a strong $\mathrm{pH}$ medium. The whole cell structure was $\mathrm{Li}$ metal anode - ion-conducting polyethylene oxide with $\mathrm{Li}\left(\mathrm{CF}_{3} \mathrm{SO}_{2}\right)_{2} \mathrm{~N}-\mathrm{LTAP}-$ aqueous electrolyte air-breathing cathode, achieving an open-circuit voltage (OCV) stabilized at $3.7 \mathrm{~V}$ at $60{ }^{\circ} \mathrm{C}$ for 2 months with a charge--discharge performance of $0.25 \mathrm{~mA} / \mathrm{cm}^{2}$ [33]. This dual dual-electrolyte configuration was further improved to significantly reduce the cell resistance to $185 \Omega \cdot \mathrm{cm}^{2}$ [34] at $60^{\circ} \mathrm{C}$ compared with that of a conventional $\mathrm{LiCl}$ solution because of the low resistance at the interface between the LTAP and the aqueous electrolyte. The cyclic performance was improved with a constant OCV at $\sim 3.69 \mathrm{~V}$ at room temperature for one month with an energy density higher than $400 \mathrm{Wh} / \mathrm{kg}$ [34]. The high capacity of the dual-electrolyte system was enhanced by phosphoric acid as the catholyte by Li et al., whose three protons introduced higher theoretical capacities and dissociation constants. This integration could effectively suppress Li3PO4 hydrolysis by adjusting the $\mathrm{pH}$ variation, demonstrating better compatibility with the LTAP [35]. Their continuous study used $\mathrm{IrO}_{2}$ as the oxygen evolution catalyst to lower the charge potential and suppress the carbon-support corrosion, reaching a maximum power density of 40 $\mathrm{mW} / \mathrm{cm}^{2}$ and a battery conversion efficiency of $80 \%$ [36]. This work also demonstrated how the internal resistance could be decreased by nearly $50 \%$ when elevating the operating temperature from 20 to $40^{\circ} \mathrm{C}$ or to less than $100 \Omega \cdot \mathrm{cm}^{2}$ when increasing the LTAP membrane conductivity to $2.5 \times 10^{-4} \mathrm{~S} / \mathrm{cm}[36]$. Thereafter, the membrane conductivity of a lithium-silver battery could be 
improved by utilizing a $25-\mu \mathrm{m}$ microporous monolayer membrane with a low area-specific impedance of $5.6 \Omega \cdot \mathrm{cm}^{-2}$, achieving a high energy density of $650 \mathrm{Wh} / \mathrm{kg}$ [37]. To outreach the optimization coverage beyond the scope of experimental observations on the electrical property of a dual-electrolyte Li-air battery, a numerical model was established using mass transport and drift-diffusion equations. Oxygen diffusivity in the cathode and separator/electrode resistance were revealed as the major limiting factors of the battery power density [38]. However, few studies could be found in follow-up research. The economic aspects of organic electrolyte were considered by several researchers. A common organic redox species, hydroquinone $\left(\mathrm{H}_{2} \mathrm{BQ}\right)$, which requires little activation energy for an outer-sphere electron transfer reaction, was utilized as the catholyte whilst graphite was used as the anode [39]. The specific discharge capacity was reported to be $395 \mathrm{mAh} / \mathrm{g}$ at the working potential of $3.4 \mathrm{~V}$ [39]. All the above-mentioned high performances enabled by the dual-electrolyte scenario are summarized in Table S1. In this paper, microfluidics will be incorporated to reduce the cost of LISICON or NASICON whilst maintaining high performance. The organic-aqueous combinations will be systematically examined by the numerical model.

\section{Conclusion}

Economic feasibility is of great importance for microfluidics-based reactor design in spite of its high area-specific performance. Improvement on the overall throughput would advance this cutting-edge research field towards industrialization to a large extent. In this work, an innovative upscaling strategy was proposed for a counter-flow-based microfluidic network. The microfluidic diffusive flow and the affiliated reactive site separation were observed to form primary, secondary and tertiary counter-flow patterns and to double the active area. The effect of the hydrodynamic condition suggested a better manipulation of the flow behaviors by utilizing the excessive pressure at the cross zone during scaling up. As a result, a significantly improved upper boundary of current 
density was observed. This unique strategy could be further optimized in terms of its reactivity, fuel utilization and interfacial mixing layer. Experimental attempts would also be promising in order to verify its practicability in the electrochemical industry chain. At present, thermodynamics as well as multiphase heat/mass transfer have greatly restricted the performance of microfluidic electrochemical devices. The numerical model developed in this study can, therefore, be useful for optimizing the microfluidics-based reactor design. By extension, identifying a combination of optimized design parameters and operation conditions could become a highly feasible means to intensify the reactivity of fuel cell processes until they reach commercial profitability.

\section{Acknowledgement}

This project is financially supported by the CRCG of the University of Hong Kong and the Scottish - Hong Kong SFC/RGC Joint Research Scheme XHKU710/14 and SFC Project H15009.

\section{Reference}

[1] Wang Y, Chen KS, Mishler J, Cho SC, Adroher XC. A review of polymer electrolyte membrane fuel cells: technology, applications, and needs on fundamental research. Applied energy. 2011;88:981-1007.

[2] Huo S, Cooper NJ, Smith TL, Park JW, Jiao K. Experimental investigation on PEM fuel cell cold start behavior containing porous metal foam as cathode flow distributor. Applied Energy. 2017;203:101-14.

[3] Ismail M, Ingham D, Hughes K, Ma L, Pourkashanian M. An efficient mathematical model for air-breathing PEM fuel cells. Applied Energy. 2014;135:490-503.

[4] Kjeang E, Djilali N, Sinton D. Microfluidic fuel cells: A review. Journal of Power Sources. 2009;186:353-69. 
[5] Cohen JL, Volpe DJ, Westly DA, Pechenik A, Abruña HD. A dual electrolyte $\mathrm{H}_{2} / \mathrm{O}_{2}$ planar membraneless microchannel fuel cell system with open circuit potentials in excess of $1.4 \mathrm{~V}$. Langmuir. 2005;21:3544-50.

[6] Lu X, Xuan J, Leung DY, Zou H, Li J, Wang H, et al. A switchable pH-differential unitized regenerative fuel cell with high performance. Journal of Power Sources. 2016;314:76-84.

[7] Whipple DT, Finke EC, Kenis PJ. Microfluidic reactor for the electrochemical reduction of carbon dioxide: the effect of pH. Electrochemical and Solid-State Letters. 2010;13:B109-B11. [8] Lu X. Electrochemical utilization of carbon dioxide: an investigation into intrinsic thermodynamics, microfluidic network and interface control. HKU Theses Online (HKUTO). 2016.

[9] Lu X, Leung DY, Wang H, Maroto-Valer MM, Xuan J. A pH-differential dual-electrolyte microfluidic electrochemical cells for $\mathrm{CO}_{2}$ utilization. Renewable Energy. 2016;95:277-85. [10] Salloum KS, Posner JD. Counter flow membraneless microfluidic fuel cell. Journal of Power Sources. 2010;195:6941-4.

[11] Xu H, Zhang H, Wang H, Leung DY, Zhang L, Cao J, et al. Counter-flow formic acid microfluidic fuel cell with high fuel utilization exceeding 90\%. Applied Energy. 2015;160:930-6. [12] Wang Y, Leung DY, Zhang H, Xuan J, Wang H. Numerical and experimental comparative study of microfluidic fuel cells with different flow configurations: Co-flow vs. counter-flow cell. Applied Energy. 2017;203:535-48.

[13] Zhang H, Xu H, Zhang L, Leung DY, Wang H, Xuan J. A counter-flow microfluidic fuel cell achieving concentrated fuel operation. Energy Procedia. 2015;75:1990-5. [14] Kjeang E, Proctor BT, Brolo AG, Harrington DA, Djilali N, Sinton D. High-performance microfluidic vanadium redox fuel cell. Electrochimica Acta. 2007;52:4942-6. 
[15] Salloum KS, Posner JD. A membraneless microfluidic fuel cell stack. Journal of Power Sources. 2011;196:1229-34.

[16] Moore S, Sinton D, Erickson D. A plate-frame flow-through microfluidic fuel cell stack. Journal of Power Sources. 2011;196:9481-7.

[17] Cohen JL, Westly DA, Pechenik A, Abruna HD. Fabrication and preliminary testing of a planar membraneless microchannel fuel cell. Journal of Power Sources. 2005;139:96-105.

[18] Wang H, Gu S, Leung DY, Xu H, Leung MK, Zhang L, et al. Development and characteristics of a membraneless microfluidic fuel cell array. Electrochimica Acta. 2014;135:467-77.

[19] Elvira KS, i Solvas XC, Wootton RC. The past, present and potential for microfluidic reactor technology in chemical synthesis. Nature chemistry. 2013;5:905-15.

[20] Lauga E, Brenner MP, Stone HA. Microfluidics: the no-slip boundary condition. Perspective. 2006;17.

[21] Lu X, Leung DY, Wang H, Xuan J. Microfluidics-based pH-differential reactor for CO2 utilization: A mathematical study. Applied Energy. 2017.

[22] Luntz AC, McCloskey BD. Nonaqueous Li-air batteries: a status report. Chemical reviews. 2014;114:11721-50.

[23] Tarascon J-M, Armand M. Issues and challenges facing rechargeable lithium batteries. Nature. 2001;414:359-67.

[24] Abraham K, Jiang Z. A polymer electrolyte-based rechargeable lithium/oxygen battery. Journal of The Electrochemical Society. 1996;143:1-5.

[25] Kuboki T, Okuyama T, Ohsaki T, Takami N. Lithium-air batteries using hydrophobic room temperature ionic liquid electrolyte. Journal of power sources. 2005;146:766-9. 
[26] Débart A, Bao J, Armstrong G, Bruce PG. An $\mathrm{O}_{2}$ cathode for rechargeable lithium batteries: the effect of a catalyst. Journal of Power Sources. 2007;174:1177-82.

[27] Li H, Wang Y, Na H, Liu H, Zhou H. Rechargeable Ni-Li battery integrated aqueous/nonaqueous system. Journal of the American Chemical Society. 2009;131:15098-9. [28] Wang Y, Zhou H. A lithium-air battery with a potential to continuously reduce $\mathrm{O}_{2}$ from air for delivering energy. Journal of Power Sources. 2010;195:358-61.

[29] He P, Wang Y, Zhou H. A Li-air fuel cell with recycle aqueous electrolyte for improved stability. Electrochemistry Communications. 2010;12:1686-9.

[30] Li L, Zhao X, Manthiram A. A dual-electrolyte rechargeable Li-air battery with phosphate buffer catholyte. Electrochemistry Communications. 2012;14:78-81.

[31] Lu Y, Goodenough JB. Rechargeable alkali-ion cathode-flow battery. Journal of Materials Chemistry. 2011;21:10113-7.

[32] Visco SJ, Nimon YS, Katz BD. Ionically conductive composites for protection of active metal anodes. Google Patents; 2007.

[33] Zhang T, Imanishi N, Hasegawa S, Hirano A, Xie J, Takeda Y, et al. Li/ polymer electrolyte/ water stable lithium-conducting glass ceramics composite for lithium-air secondary batteries with an aqueous electrolyte. Journal of The Electrochemical Society. 2008;155:A965-A9. [34] Zhang T, Imanishi N, Shimonishi Y, Hirano A, Takeda Y, Yamamoto O, et al. A novel high energy density rechargeable lithium/air battery. Chemical Communications. 2010;46:1661-3. [35] Li L, Zhao X, Fu Y, Manthiram A. Polyprotic acid catholyte for high capacity dualelectrolyte Li-air batteries. Physical Chemistry Chemical Physics. 2012;14:12737-40. [36] Li L, Manthiram A. Dual-electrolyte lithium-air batteries: influence of catalyst, temperature, and solid-electrolyte conductivity on the efficiency and power density. Journal of Materials Chemistry A. 2013;1:5121-7. 
[37] Zhang D, Yan K, Wu F, Zhang C. A high power density dual-electrolyte lithium-silver battery with Celgard® 2325 separator. Electrochimica Acta. 2014;116:429-33.

[38] Andrei P, Zheng JP, Hendrickson M, Plichta EJ. Modeling of Li-air batteries with dual electrolyte. Journal of The Electrochemical Society. 2012;159:A770-A80.

[39] Ding Y, Yu G. A bio-inspired, heavy-metal-free, dual-electrolyte liquid battery towards sustainable energy storage. Angewandte Chemie International Edition. 2016;55:4772-6.

[40] Cheng S, Chan K-Y. High-voltage dual electrolyte electrochemical power sources. ECS

Transactions. 2010;25:213-9.

\section{Supplementary}

Table S1. Performances of dual electrolyte electrochemical devices.

\begin{tabular}{|c|c|c|c|c|c|c|c|c|c|c|}
\hline \multicolumn{11}{|c|}{ Fuel cell and electrolyzer } \\
\hline Type & $\begin{array}{l}\text { Channel width } \times \text { thickness } \\
(\mathrm{mm})\end{array}$ & \multicolumn{2}{|l|}{ Electrode } & \multicolumn{3}{|l|}{ Electrolyte } & $\begin{array}{l}\text { OCV } \\
\text { (V) }\end{array}$ & \multicolumn{3}{|c|}{$\begin{array}{l}\text { Peak power density } \\
\left(\mathrm{mW} / \mathrm{cm}^{2}\right)\end{array}$} \\
\hline \multirow{3}{*}{$\begin{array}{l}\mathrm{H}_{2} / \mathrm{O}_{2} \text { fuel cell } \\
{[5]}\end{array}$} & $1 \times 0.25$ & \multicolumn{2}{|l|}{$\mathrm{Ta} / \mathrm{Pt}$} & \multicolumn{3}{|c|}{$0.1 \mathrm{M} \mathrm{KOH} / 0.1 \mathrm{M} \mathrm{H}_{2} \mathrm{SO}_{4}$} & 1.40 & \multicolumn{3}{|c|}{0.96} \\
\hline & $1 \times 0.25$ & \multicolumn{2}{|l|}{$\mathrm{Ta} / \mathrm{Pt}$} & \multicolumn{3}{|c|}{$0.1 \mathrm{M} \mathrm{H}_{2} \mathrm{SO}_{4} / 0.1 \mathrm{M} \mathrm{H}_{2} \mathrm{SO}_{4}$} & 0.89 & \multicolumn{3}{|l|}{0.18} \\
\hline & $1 \times 0.25$ & \multicolumn{2}{|l|}{$\mathrm{Ta} / \mathrm{Pt}$} & \multicolumn{3}{|c|}{$0.1 \mathrm{M} \mathrm{KOH} / 0.1 \mathrm{M} \mathrm{KOH}$} & 0.93 & \multicolumn{3}{|l|}{0.286} \\
\hline \multirow{2}{*}{$\begin{array}{l}\mathrm{H}_{2} / \mathrm{O}_{2} \text { fuel cell } \\
{[40]}\end{array}$} & & \multirow{2}{*}{\multicolumn{2}{|c|}{$\begin{array}{l}\mathrm{Pt} / \mathrm{PtMoO}_{3} \\
\mathrm{Pt} / \mathrm{PtMoO} \\
\end{array}$}} & \multicolumn{3}{|c|}{$3.5 \mathrm{M} \mathrm{NaOH} / 2.5 \mathrm{M} \mathrm{H}_{2} \mathrm{SO}_{4}$} & 1.6 & \multicolumn{3}{|l|}{20} \\
\hline & & & & \multirow{2}{*}{\multicolumn{3}{|c|}{$\frac{3.5 \mathrm{M} \mathrm{NaOH} / 3.5 \mathrm{M} \mathrm{NaOH}}{3 \mathrm{M} \mathrm{KOH} / 3 \mathrm{M} \mathrm{H}_{2} \mathrm{SO}_{4}}$}} & 1.1 & \multicolumn{3}{|l|}{8.03} \\
\hline $\begin{array}{l}\begin{array}{l}\mathrm{H}_{2} / \mathrm{O}_{2} \\
{[8]}\end{array} \\
\end{array}$ & $2 \times 0.3$ & \multicolumn{2}{|l|}{$\begin{array}{l}\mathrm{Pt} / \mathrm{PtMoO} \mathrm{O}_{3} \\
\mathrm{PtRu} / \mathrm{PtRu}\end{array}$} & & & & 1.01 & 480 & & \\
\hline \multirow{3}{*}{$\begin{array}{l}\mathrm{H}_{2} / \mathrm{O}_{2} \text { fuel cell } \\
{[6]}\end{array}$} & $2 \times 0.3$ & \multicolumn{2}{|l|}{ PtRu/PtRu } & \multicolumn{3}{|c|}{$3 \mathrm{M} \mathrm{KOH} / 3 \mathrm{M} \mathrm{H}_{2} \mathrm{SO}_{4}$} & 1.89 & \multicolumn{3}{|l|}{1300} \\
\hline & $2 \times 0.3$ & \multicolumn{2}{|l|}{$\mathrm{PtRu} / \mathrm{PtRu}$} & \multicolumn{3}{|c|}{$3 \mathrm{M} \mathrm{H}_{2} \mathrm{SO}_{4} / 3 \mathrm{M} \mathrm{H}_{2} \mathrm{SO}_{4}$} & 0.8 & \multicolumn{3}{|l|}{477} \\
\hline & $2 \times 0.3$ & \multicolumn{2}{|l|}{$\mathrm{PtRu} / \mathrm{PtRu}$} & \multicolumn{3}{|c|}{$3 \mathrm{M} \mathrm{KOH} / 3 \mathrm{M} \mathrm{KOH}$} & 0.9 & 310 & & \\
\hline $\mathrm{H}_{2} \mathrm{O}$ electrolysis & $2 \times 0.3$ & $\mathrm{PtRu} / \mathrm{PtRu}$ & & $3 \mathrm{M} \mathrm{H}_{2} \mathrm{SO}_{4}$ & $\mathrm{I} \mathrm{KOH}$ & & 0.57 & 73.6 & & \\
\hline & $2 \times 0.3$ & $\mathrm{PtRu} / \mathrm{PtRu}$ & & $3 \mathrm{M} \mathrm{H}_{2} \mathrm{SO}_{4}$ & $\mathrm{IH}_{2} \mathrm{SO}_{4}$ & & 1.46 & 58.5 & & \\
\hline & $2 \times 0.3$ & PtRu/PtRu & & $3 \mathrm{M} \mathrm{KOH} / 3$ & $\mathrm{KOH}$ & & 1.46 & 57.1 & & \\
\hline $\begin{array}{l}\mathrm{CO}_{2} \text { electrolysis } \\
{[9]}\end{array}$ & $2 \times 0.3$ & Pb-PtRu & & $0.01 \mathrm{M} \mathrm{H}_{2} \mathrm{~S}$ & $1 \mathrm{M} \mathrm{KOH}$ & & 1.2 & 48.5 & & \\
\hline Li-air batteries & & & & & & & & & & \\
\hline $\begin{array}{l}\text { Electrode } \\
\text { (cathode/anode) }\end{array}$ & $\begin{array}{l}\text { Electrolyte } \\
\text { (catholyte/anolyte) }\end{array}$ & $\begin{array}{l}\text { Membrane } \\
\text { (conductivity) }\end{array}$ & $\begin{array}{l}\text { Internal } \\
\text { resistance } \\
(\Omega)\end{array}$ & $\begin{array}{l}\text { Working } \\
\text { current } \\
\text { density } \\
\left(\mathrm{mA} / \mathrm{cm}^{2}\right)\end{array}$ & $\begin{array}{l}\text { Peak } \\
\text { capacity } \\
(\mathrm{Ah} / \mathrm{kg})\end{array}$ & $\begin{array}{l}\text { Voltage } \\
\text { (V) }\end{array}$ & $\begin{array}{l}\text { Energy } \\
\text { density } \\
\text { (Wh/kg) }\end{array}$ & $\begin{array}{l}\text { Peak } \\
\text { power } \\
\text { density } \\
\left(\mathrm{mW} / \mathrm{cm}^{2}\right)\end{array}$ & $\begin{array}{l}\text { Energy } \\
\text { conversion } \\
\text { efficiency } \\
(\%)\end{array}$ & $\begin{array}{l}\text { Faradaic } \\
\text { efficiency } \\
(\%)\end{array}$ \\
\hline $\begin{array}{l}\mathrm{Ni}(\mathrm{OH})_{2} / \mathrm{Li} \\
{[27]}\end{array}$ & $\mathrm{LiOH}+\mathrm{KOH} / \mathrm{LiClO} 4$ & LISICON & 67 & 0.32 & 264 & 3.47 & 857 & & & $95-96$ \\
\hline $\mathrm{Mn}_{3} \mathrm{O}_{4} / \mathrm{Li}[28]$ & $\mathrm{KOH} /$ Organic electrolyte & LISICON & 120 & 0.5 & 50,000 & 2.8 & 140,000 & $\begin{array}{l}3200 \\
\mathrm{~mW} / \mathrm{g} \quad \text { at } \\
11 \mathrm{~mA} / \mathrm{cm}^{2}\end{array}$ & & \\
\hline $\mathrm{Mn}_{3} \mathrm{O}_{4} / \mathrm{Li}[29]$ & KOH/Organic electrolyte & LISICON & & 0.5 & 19,000 & 2.8 & 53,200 & $\begin{array}{l}1127 \\
\mathrm{~mW} / \mathrm{g} \text { at } 3 \\
\mathrm{~mA} / \mathrm{cm}^{2}\end{array}$ & & \\
\hline $\mathrm{Pt} / \mathrm{Li}[30]$ & $\begin{array}{ll}\mathrm{H}_{3} \mathrm{PO}_{4}+\mathrm{LiH}_{2} \mathrm{PO}_{4} / \mathrm{LiPF}_{6} \text { in } \\
\mathrm{EC} / \mathrm{DEC}\end{array}$ & LISICON & 258 & 0.5 & 221 & & 770 & $\begin{array}{l}11.9 \text { at } 6.5 \\
\mathrm{~mA} / \mathrm{cm}^{2}\end{array}$ & & \\
\hline $\begin{array}{l}\mathrm{K}_{3} \mathrm{Fe}(\mathrm{CN})_{6} / \mathrm{Li} \\
{[31]}\end{array}$ & $\begin{array}{l}\text { Aqueous } \\
\text { catholyte/LiPF }+\mathrm{EC}+\mathrm{DEC}\end{array}$ & NASICON & $210 \Omega \mathrm{cm}^{2}$ & 0.5 & $\begin{array}{l}5.25 \\
\mathrm{mAh}\end{array}$ & 3.4 & & $\begin{array}{l}17 \text { at } 11 \\
\mathrm{~mA} / \mathrm{cm}^{2}\end{array}$ & & $97-99$ \\
\hline $\mathrm{Pt} / \mathrm{Li}[33]$ & $\mathrm{LiCl} / \mathrm{PEO}_{18} \mathrm{LiTFSI}$ & LISICON & $\begin{array}{l}539 \\
\Omega \cdot \mathrm{cm}^{2}\end{array}$ & 0.25 & & 3.8 & & & & \\
\hline $\mathrm{Pt} / \mathrm{Li}[34]$ & $\begin{array}{l}\mathrm{HOAc}+\mathrm{H}_{2} \mathrm{O}+\mathrm{LiOAc} / \\
\mathrm{PEO}_{18} \mathrm{LiTFSI}\end{array}$ & NASICON & $\begin{array}{l}185 \\
\Omega \cdot \mathrm{cm}^{2}\end{array}$ & 0.5 & 225 & 3.46 & 779 & & & \\
\hline $\mathrm{Pt} / \mathrm{Li}[35]$ & $\begin{array}{l}\text { Aqueous } \\
\text { catholyte/ } / \mathrm{H}_{3} \mathrm{PO}_{4}+\mathrm{Li}_{2} \mathrm{SO}_{4}\end{array}$ & NASICON & $\begin{array}{l}180 \\
\Omega \cdot \mathrm{cm}^{2} \\
\end{array}$ & 0.5 & 740 & 3.3 & 2442 & & & \\
\hline $\mathrm{PtIrO}_{2} / \mathrm{Li}[36]$ & $\begin{array}{l}\mathrm{H}_{3} \mathrm{PO}_{4}+\mathrm{Li}_{2} \mathrm{PO}_{4} / \\
\mathrm{LiPF}_{6}+\mathrm{EC}+\mathrm{DEC}\end{array}$ & NASICON & $\begin{array}{l}100 \\
\Omega \cdot \mathrm{cm}^{2}\end{array}$ & 2 & & 3.5 & & $\begin{array}{l}40 \mathrm{at} \\
2 \mathrm{~mA} / \mathrm{cm}^{2}\end{array}$ & 80 & \\
\hline $\mathrm{Ag}_{2} \mathrm{O} / \mathrm{Li}[37]$ & $\mathrm{LiOH}+\mathrm{LiNO}_{3} / \mathrm{PC}+\mathrm{DMC}$ & NASICON & 90 & 1 & 200 & 3.25 & 650 & $\begin{array}{l}29.9 \text { at } 18 \\
\mathrm{~mA} / \mathrm{cm}^{2}\end{array}$ & & \\
\hline Graphite/Li [39] & $\mathrm{H}_{2} \mathrm{BQ} /$ Organic electrolyte & NASICON & & & 395 & 3.4 & 1343 & & 92 & 99 \\
\hline
\end{tabular}

